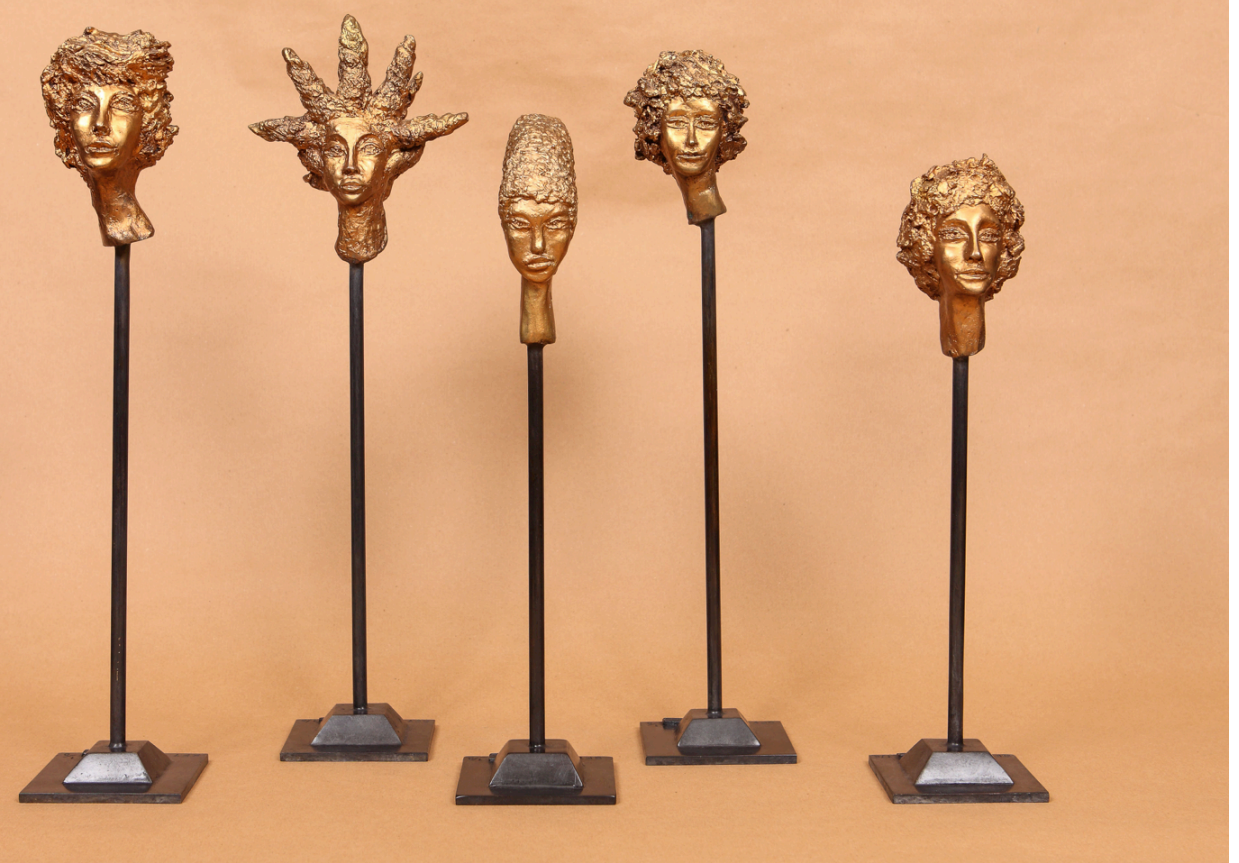

Babylone by Sylviane Toporkoff 


\author{
Introduction - Photography and school cultures ${ }^{1}$ \\ Introduction - Photographie et cultures scolaires \\ Introducción - Fotografía y culturas escolares
}

\title{
Carlos Martínez Valle
}

Complutense University of Madrid, Spain

\begin{abstract}
Certos momentos há da vida que deviam ficar fixados, protegidos do tempo, não apenas consignados, por exemplo, [...] em foto, cine e vídeo, o que interessava mesmo era que o próprio que os viveu ou tinha feito viver pudesse permanecer para todo o sempre à vista dos seus vindouros.
\end{abstract}

(José Saramago)

This special issue on "Photography and School Cultures" from Encounters in Theory and History of Education / Rencontres en Théorie et Histoire de l'Éducation / Encuentros en Teoría e Historia de la educación presents a series of articles in English, French and Spanish from a wide spectrum of geographical origins and focuses, in which both established scholars and young researchers contribute research on rural and urban schools, formal and informal education and related norms, models, representations, and practices.

In the first section of the issue, New approaches and points of view for photographic analysis, Ian Grosvenor opens with 'We seek revelation with our eyes': Engaging with school cultures through montage. The article, the result of an exploratory innovative device for reading images based on Walter Benjamin's "montage" method, challenges criticisms that reject the sufficiency of pictures as sources for the History of Education, but also dismisses contextual or serial methods. Grosvenor sent six photos of English schools to five historians of education, four European and one Argentinean. As sort of objets trouvés, each of these photos was accompanied by different and carefully selected, but not necessarily matching, texts. The texts widened the spectrum of feelings and the meanings of the pictures by appealing to the senses

\footnotetext{
1 This introduction was written and the special issue was guest-edited in the frame of a coordinated research project (EDU2014-52498-C2-1-P) financed by the Spanish Programa Estatal de Fomento de la Investigación Científica y Técnica de Excelencia, Subprograma Estatal de Generación de Conocimiento, within the Plan Estatal de Investigación Científica y Técnica y de Innovación, 2013-2016.
} 
(smell, sight, or touch) and introducing emotions (anguish, order, or attraction), fostering an almost synaesthetic approach to taking in the images. For instance, in an almost cinematographic way, a photograph of a void corridor was accompanied by text describing children running through corridors and the anguish felt by a latecomer to silent corridors. So, the text could be read as a kind of voiceover for the photo. In response, the historians shared their feelings and reflections about the pictures and texts, creating a montage of discourses, photographs, and texts. The powerful method of this photobook project opens the door to other areas of study, in particular around the world of school memories (smell, which is directly connected with memory, is the first sense addressed by the accompanying texts). As photographs (and odours) are inevitably linked with memory, the intricate relation of memory and History is a recurrent, although not explicitly addressed, concept in many of the articles. However, we have chosen not to follow the threads of the memory in this issue.

Sylvain Wagnon's La photographie de classe dans l'école française: une source sousestimée de compréhension de l'histoire de école, interface entre sphères privée et publique (XIXe-XXIe) aims not only at analyzing photos as sources for the history of school practices but as a way to frame and assess the whole school culture. The article explores the regulation of the class photograph, which has become a part of the rituals and culture of the French school. Furthermore, it studies the photo as a recursive instrument, i.e., as a self-reflective instrument, and as an idealized image and model for the French school. This analysis of photography as an instrument of learning and knowledge links Wagnon's piece with the final article of the issue, by Lisón.

In a recent seminar in Majorca, Juan Luis Rubio illustrated how the discovery of photographs has sparked his research on the history of science in Spain. And it was through pictures that Mar del Pozo (2015) discovered the lack of mandatory fascist symbols in many religious schools during Franco's dictatorship. Thus, photographs can serve as historical sources, but they seem to be particularly useful at sparking questions and pointing to neglected or overlooked issues, fuelling research. This is one of the issues at stake in the second section, Forgotten Historical Issues and Photography. In Chile, one of these overlooked issues was the "tiro escolar," or gun shooting lessons, which are the focus of Toy soldiers: the armed body of Chilean students. Military instruction and shooting lessons in school (ca. 1880 - ca.1930). Author Pablo Andrés Toro brings back into focus the debates around shooting instruction in schools, which was practiced in different forms in many countries of the western hemisphere. It was an even more disconcerting and intriguing practice in Chile as it was directed at middle and lower classes in a clime of social tensions. Rosa Fátima de Souza's article also delves into a little studied area in Representations of rural primary school in Brazil (São Paulo, 1933-1943). De Souza uses powerful photographs of rural schools that appeared in inspection reports and professional publications to illustrate their effect on the educational system. Although these neglected sources apparently aimed at stating the situation of São Paulo State's educational 
system, rather than denouncing the divide between rural and urban schools, they helped to perpetuate it. For instance, the image of the neglected rural school deterred the best teacher trainees from beginning their professional career in a rural area. Photographs became, in this way, a sort of performative instrument of rural-urban school segregation and an instrument for creating a rural school culture. De Souza's article thus reminds us of the character of photos as social and discursive instruments rather than as mere mirrors of facts.

The third section, Photography and historical issues in Spanish education, brings together two articles on Spanish educational history. In his article Photography and school culture in post-war Spain (1939-1945). A look at Majorca, post-doc student Biel Barceló traces a parallel study of the photographic repositories of the Balearic Islands and their possible uses in working out some of the historical issues in Spanish education during Franco's dictatorship. Large series of photographs, in this case the photographic repositories of a region, would allow one to study, for instance, the aforementioned problem of the fulfilment of the law that imposed the presence of fascist symbols in all classrooms. In studying this aspect, we could measure the evolution of the connivance of the church with the project of the dictatorship. Iconographic sources could be of use in advancing, for instance, our knowledge about the transition from the ungraded to the graded school. Photography series could help us to analyze changes in school practices or even more subtle transformations, for instance, the evolution of the placement of the teacher's desk in relation to the classroom entrance, the blackboard, and the students, or the transformations in uses of the blackboard, which have been studied by Sylvain Wagnon elsewhere.

Bernat Sureda and Francisca Comas devote their article, Album photographique scolaire, histoire et configuration de l'identité des établissements scolaires: le cas du collège Sant Josep Obrer à Palma, to another neglected but important issue that could become an important debate in the coming years, namely, the adoption of new progressive values and the transformation of many Catholic schools in the process of the Church's aggiornamento and in the wake of Vatican II. This transformation allowed these private institutions to open up to their neighbouring communities, and become instrumental in the development of Spanish civil society during the dictatorship and in preparing for the arrival of democracy (Bruno-Jofre and Igelmo, 2016).

The closing section, Digital photography and future school cultures, addresses the role that new information and communication technology systems play in the learning processes of young people for whom school is no longer the centre of knowledge and socialization. José Carmelo Lisón explores, from an anthropological perspective, not photographs as a source of History, but photography as a learning practice. His article Cultura escolar, móviles y fotografía digital examines how digital cameras and in particular smartphones have changed the ways of creating, processing, and communicating information among these youngsters outside of school. Lisón reminds us that these new practices go beyond mere knowledge acquisition, but 
convey times, ethos, organizational forms, and hierarchies that are directly opposed to those of the traditional teacher-centred, memory and text-based school. The article also explores some of the changes that the use of digital photography could introduce in our schools. Furthermore, Lisón's article reframes the rest of the articles in this issue by considering the differences between analogical and digital ways of producing, communicating about, and consuming photographs, reminding us of the fixed, authoritative character of analogical photography and its insertion in social practices that were basically logocentric, just as those of today's young people are becoming iconocentric. This change is a problem that historians and philosophers of education can no longer afford to ignore.

This issue is based on the presupposition that iconographic (photo) analysis could be used as another source for the History of Education. New Histories, and, in particular, iconographic-based history, require sophisticated analytical approaches. It is difficult to analyze iconic sources in the same way that positive History analyzes written sources, as the historian has to avoid being trapped by their false, flat evidence. Historians who use photographs require more historical sensibility, imagination, and awareness; clearly defined problems as a guide for questioning the images; and more contexts from which to explain the processes and conditions of their creation and conservation. The articles of this special issue are good examples of this new approach.

\section{References:}

Bruno-Jofre, R., and Igelmo, J. (2016). Catholic Education in the Wake of Vatican II. Toronto: University of Toronto Press.

Pozo Andrés, M. M. del (2015). Hanging Spain on The Walls: Images and Building of National Identity from the Schools (1875-1975). In F. Sabaté (Ed.), Conditioned Identities. Wishedfor and Unwished-for Identities (pp. 175-202). Frankfurt: Peter Lang. 